\title{
Two Protocols of Cryopreservation of Goat Semen with the Use of Computer-Assisted Semen Analysis System
}

\author{
R. KOZDROWSKI, A. DUBIEL, W. BIELAS, M. DZIĘCIOł
}

Department and Clinic of Reproduction, Ruminants Diseases and Animal Health Protection Wrocław University of Environmental and Life Sciences, Wrocław, Poland

Received February 26, 2007

Accepted October 2, 2007

\begin{abstract}
Kozdrowski R., A. Dubiel, W. Bielas, M. Dzięcioł: Two Protocols of Cryopreservation of Goat Semen with the Use of Computer-Assisted Semen Analysis System.Acta Vet. Brno 2007, 76: 601-604.

The objective of the study was a comparison of two protocols of goat semen cryopreservation with the use of computer-assisted semen analysis system. Twenty ejaculates obtained with electroejaculation method were assessed. Each ejaculate was divided in half and frozen according to two protocols. In protocol I semen was centrifuged in order to remove its plasma and diluted in Tris buffer extender containing glucose, citric acid and glycerol with $20 \%$ addition of egg yolk. Protocol II did not include removal of plasma and the extender contained $1.5 \%$ egg yolk. It was shown that the removal of semen plasma improved motility of goat spermatozoa following freezing/thawing with respect to the following motility indicators: motility, average path velocity, amplitude of lateral head displacement at $p<0.05$, and straight velocity, straightness and linearity at $p<0.01$. In conclusion, the removal of semen plasma through centrifugation improved motility properties of goat semen following the freezing/thawing procedure.
\end{abstract}

Semen plasma, spermatozoa, motility, freezing, cryopreservation, CASA, semen evaluation

Semen crypreservation causes ultrastructural, biochemical and functional damage of spermatozoa, resulting in their decreased motility and viability. A specific problem limiting post-freezing properties of goat semen is the presence in semen plasma of an enzyme derived from bulbo-urethral glands, coagulating egg yolk (egg yolk coagulating enzyme - EYCE) (Leboeuf et al. 2000). EYCE has been characterized as phospholipase A which hydrolyses egg yolk lecithin to fatty acids and lisolecithin. Lisolecithin is toxic to goat spermatozoa. The toxic effect can be partly eliminated by the removal of semen plasma which results in an increased proportion of live and motile spermatozoa.

Motility of spermatozoa is among the most important indicators in semen quality assessment. At present the objective assessment of motility of spermatozoa is possible due to computer analysis considering many motility properties (Verstegen et al. 2002; Klimowicz et al. 2005). The objective of this study was to compare motility properties of goat spermatozoa subjected to freezing/thawing with or without a prior removal of plasma, with the use of the computer-assisted semen analysis system (CASA).

\section{Materials and Methods}

Semen was collected from 4 fertile male goats (each male had produced offspring, French Alpine breed), 3 - 4 years old, from January to March with the electroejaculation method. The males were fed a diet composed of hay, carrot and oats and were prepared for the operation by 12-hour starvation and premedication with xylasin $\left(\right.$ Sedazin $\left.^{\circledR}\right)$ at the dose of $1.5 \mathrm{mg} / 10 \mathrm{~kg}$ b.w.

Semen was collected into glass containers with water coat at a temperature of $37^{\circ} \mathrm{C}$. Following collection, the ejaculate volume was measured. The percentage of motile spermatozoa was determined in a light microscope with a thermostable table of $37^{\circ} \mathrm{C}$, under $\times 200$ magnification, and spermatozoa concentration was calculated in the Thom-Zeiss chamber.

Ejaculates of a volume exceeding $1 \mathrm{ml}$, sperm motility $>80 \%$ and sperm concentration $>10 \times 10^{8} / \mathrm{ml}$ were

Address for correspondence:

Dr. R. Kozdrowski

Department and Clinic of Reproduction,

Ruminants Diseases and Animal Health Protection

Wrocław University of Environmental and Life Sciences

Plac Grundwaldzki 49, 50-366 Wrocław, Poland

Phone: +48713205313

E-mail: rkozdrowski@wp.p

http://www.vfu.cz/acta-vet/actavet.htm 
qualified for freezing. Five ejaculates from each male were thus qualified. Each ejaculate was divided in two equal parts and frozen according to the methods described below. Two extenders used in Australia for semen cryopreservation were used for freezing.

In protocol I, semen was diluted at $33{ }^{\circ} \mathrm{C}$ in a $1: 4$ ratio in a buffer of the following composition: Tris 274.1 $\mathrm{mM}$, glucose $55.5 \mathrm{mM}$, citric acid $87.08 \mathrm{mM}$, and then centrifuged for $10 \mathrm{~min}$ at $1500 \mathrm{~g}$ in order to remove semen plasma. Following centrifugation and removal of supernatant, the sediment was suspended as $1: 1$ in an extender of the following composition: buffer $80 \mathrm{ml}$ and egg yolk $20 \mathrm{ml}$. Thus diluted semen was cooled to $10^{\circ} \mathrm{C}$ and then half of the calculated dose of an extender of the following composition: glycerol $8 \mathrm{ml}$, egg yolk $20 \mathrm{ml}$, buffer $72 \mathrm{ml}$ was added. After $30 \mathrm{~min}$ the other half of the extender was added, to the final concentration of $60 \times 10^{6}$ spermatozoa in the volume of $0.25 \mathrm{ml}$.

In protocol II, the semen was diluted at $33{ }^{\circ} \mathrm{C}$ with an extender of the following composition: $375 \mathrm{mM}$ Tris, $41.625 \mathrm{mM}$ glucose, $124.0 \mathrm{mM}$ citric acid, $6 \%$ glycerol and $1.5 \%$ egg yolk, to the final concentration of $60 \times 10^{6}$ spermatozoa in the volume of $0.25 \mathrm{ml}$. This extender is recommended by Ritar and Salomon (1983) for use without prior plasma removal.

In protocols I and II the semen was cooled to $5{ }^{\circ} \mathrm{C}$ during $120 \mathrm{~min}$, packed in straws of $0.25 \mathrm{ml}$ volume, placed horizontally $5 \mathrm{~cm}$ above the surface of liquid nitrogen for $10 \mathrm{~min}$, and the straws were then plunged in liquid nitrogen. After 7 days the straws were thawed in a water bath of $40{ }^{\circ} \mathrm{C}$ during $30 \mathrm{~s}$.

Using the same methods that were applied to fresh semen, the percentage of motile spermatozoa was determined for freezing-thawing semen and the assessment of motility indicators was performed with the CASA system (HTM IVOS 12.2, Hamilton-Throne Biosciences MA, USA), coupled with phase-contrast microscope, video camera and computer which made it possible to register and analyse the data. Four $\mu 1$ of semen diluted $\times 40$ with an extender of the following composition: Tris $274.1 \mathrm{mM}$, glucose $55.5 \mathrm{mM}$, citric acid $87.08 \mathrm{mM}$ were placed in chamber $20 \mu \mathrm{m}$ deep (Leja 4, Leja products B.V. Holland) on a thermo-stable plate heated to 37 ${ }^{\circ} \mathrm{C}$. Prior to the analysis it was necessary to enter technical parameters enabling a correct identification of goat spermatozoa. The following motility indicators were measured: VAP (average path velocity) - average velocity of the smoothed cell path $(\mu \mathrm{m} / \mathrm{s})$, VSL (straight velocity) - average velocity measured for the movement along a straight line from beginning to end ( $\mu \mathrm{m} / \mathrm{s})$, VCL (cell velocity) - average velocity measured along the actual path of the spermatozoon $(\mu \mathrm{m} / \mathrm{s})$, ALH (amplitude of lateral head displacement) - amplitude of head oscillation ( $\mu \mathrm{m})$, STR (straightness) - straight line character of movement as a ratio of VSL/VAP (\%), LIN (linearity) - linearity of movement as a ratio VCL/VAP (\%), MOT (motility) - motile spermatozoa (\%), PMOT (progressive motility) - spermatozoa with progressive movement (\%) i.e. with VAP of $75 \mu \mathrm{m} / \mathrm{sec}$ and STR of $80 \%$ and RAP (rapid) - proportion of rapidly moving spermatozoa (\%). Each time the semen sample was scanned in 5 automatically selected fields, and the mean values of the five fields were used for statistical analysis. Following analysis, digital video recording of the last field was examined in order to confirm that all the spermatozoa were identified and their movement correctly interpreted by the device. Static cells were marked on the screen with a large red dot, the trajectory of spermatozoa interpreted as abnormal was marked with purple, the trajectory of normally moving spermatozoa with green.

The results were presented as mean \pm standard deviation; statistical analysis was based on Student's $t$-test at the significance level of $p<0.05$ and $p<0.01$.

\section{Results}

Data on the proportion of motile spermatozoa estimated with conventional and computer methods in fresh and freezing/thawing semen are presented in Table 1.

Table 1. Percentage of motile spermatozoa measured with conventional and CASA method in fresh and freezing/thawing semen (mean \pm standard deviation)

\begin{tabular}{|c|c|c|c|c|c|}
\hline \multicolumn{2}{|c|}{ Fresh semen } & \multicolumn{2}{c|}{$\begin{array}{c}\text { Freezing/thawing semen } \\
\text { Protocol I }\end{array}$} & \multicolumn{2}{c|}{$\begin{array}{c}\text { Freezing/thawing semen } \\
\text { Protocol II }\end{array}$} \\
\hline $\begin{array}{c}\text { Conventional } \\
\text { method }\end{array}$ & $\begin{array}{c}\text { CASA } \\
\text { (MOT) }\end{array}$ & $\begin{array}{c}\text { Conventional } \\
\text { method }\end{array}$ & $\begin{array}{c}\text { CASA } \\
(\text { MOT })\end{array}$ & $\begin{array}{c}\text { Conventional } \\
\text { method }\end{array}$ & $\begin{array}{c}\text { CASA } \\
(\text { MOT })\end{array}$ \\
\hline $87.50 \pm 4.62 \%$ & $86.45 \pm 4.69 \%$ & $28.12 \pm 6.51 \% \%^{\mathrm{a}}$ & $23.46 \pm 7.45 \%^{\mathrm{b}}$ & $22.50 \pm 5.97 \%^{\mathrm{a}}$ & $19.30 \pm 4.80 \%{ }^{\mathrm{b}}$ \\
\hline
\end{tabular}

Mean values marked with the same letter - difference $p<0.05$

The percentage of motile spermatozoa determined with the microscope method was higher than that estimated with the computer method and statistically significant differences were found between the two protocols. The percentage of motile spermatozoa (MOT) following thawing, estimated with conventional and computer method, was significantly higher for protocol I $(p<0.05)$. 
Data on the remaining indicators of spermatozoa motility estimated with the computerassisted semen analysis HTM IVOS are presented in Table 2.

Table 2. Comparison of motility properties of freezing/thawing semen measured with CASA (mean \pm standard deviation)

\begin{tabular}{|c|c|c|c|c|c|c|c|c|}
\hline & VAP $(\mu \mathrm{m} / \mathrm{s})$ & VSL $(\mu \mathrm{m} / \mathrm{s})$ & VCL $(\mu \mathrm{m} / \mathrm{s})$ & $\begin{array}{c}\text { STR } \\
(\%)\end{array}$ & $\begin{array}{c}\text { LIN } \\
(\%)\end{array}$ & $\begin{array}{c}\text { PMOT } \\
(\%)\end{array}$ & $\begin{array}{r}\text { RAP } \\
(\%)\end{array}$ & $\begin{array}{r}\text { ALH } \\
(\mu \mathrm{m})\end{array}$ \\
\hline Protocol I & $\begin{array}{c}78.33 \\
\pm 6.53^{\mathrm{a}}\end{array}$ & $\begin{array}{c}68.46 \\
\pm 7.20^{\mathrm{b}}\end{array}$ & $\begin{array}{c}129.20 \\
\pm 5.47\end{array}$ & $\begin{array}{c}82.30 \\
\pm 3.01^{\mathrm{b}}\end{array}$ & $\begin{array}{c}52.00 \\
\pm 4.14^{\mathrm{b}}\end{array}$ & $\begin{array}{r}6.05 \\
\pm 1.36\end{array}$ & $\begin{array}{r}9.95 \\
\pm 2.06\end{array}$ & $\begin{array}{r}5.69 \\
\pm 0.52^{\mathrm{a}}\end{array}$ \\
\hline Protocol II & 74.61 & 62.56 & 128.26 & 78.93 & 48.00 & 6.06 & 10.73 & 5.01 \\
& $\pm 4.68^{\mathrm{a}}$ & $\pm 4.72^{\mathrm{b}}$ & \pm 4.42 & $\pm 2.66^{\mathrm{b}}$ & $\pm 3.27^{\mathrm{b}}$ & \pm 1.83 & \pm 3.51 & $\pm 0.35^{\mathrm{a}}$ \\
\hline
\end{tabular}

Mean values marked with the same letter in columns, a - difference at $p<0.05, \mathrm{~b}-$ difference at $p<0.01$

It was shown that the removal of plasma improved motility properties of goat semen following freezing/thawing with respect to the following indicators: VAP, ALH at $p<0.05$, VSL, STR, LIN at $p<0.01$.

\section{Discussion}

The microscope estimate of spermatozoa motility in all cases yielded higher values, but not significantly different from those obtained with the computer method. Also in other studies involving analysis of dog semen motility properties, conventional assessment resulted in higher values (Klimowicz et al. 2005). Likewise, Tuli et al. (1992) obtained similar results estimating spermatozoa motility with subjective and computer methods in fresh goat and boar semen, and freezing/thawing bull, goat and boar semen. It should be noted that the results of estimates of the percentage of motile spermatozoa following freezing/thawing obtained by different authors are not uniform, which indicates that an array of factors may affect post-freezing properties of goat semen. For example, Tuli and Holtz (1994) obtained a considerably higher percentage of motile spermatozoa and observed no favourable effect of the removal of semen plasma. According to Ritar and Salamon (1982) the removal of semen plasma has a favourable effect on its freezing/thawing properties which was confirmed in our studies. Similar results with regard to the percentage of motile spermatozoa were presented by Ritar et al. (1990) and Ritar and Salamon (1991). According to Ritar et al. (1990) freezing/thawing properties of goat semen are affected, among others, by the temperature at which straws are filled with semen, degree of dilution, methods of cooling and freezing, and the way of semen storage. They point to the fact that goat semen freezes better in pellets than in straws. Ritar and Salamon (1991) think that the motility of goat semen after freezing/thawing is influenced by an array of interacting factors, such as individual features of the male, month of semen collection, quantity of added yolk and the removal of semen plasma. Based on the criteria adopted in our own studies, it can be said that goat semen shows better motility properties following freezing/thawing with prior removal of plasma. In protocol I the percentage of motile spermatozoa (measured conventionally and with the computer method) was significantly higher compared to protocol II. Besides, the spermatozoa showed a higher ALH, a property that reflects the ability to penetrate mucus in the uterine cervix and to unite with the oocyte (Verstegen et al. 2002). Also most indicators characterising velocity of spermatozoa, such as VAP, VSL, STR and LIN were significantly higher when method I was applied, and such properties are correlated with the fertilising ability of spermatozoa (Verstegen et al. 2002). In summary, it can be said that the removal of semen plasma through centrifugation improved motility properties of goat semen following freezing/thawing procedure. 


\section{Srovnání dvou protokolů kryokonzervace semene kozlů s využitím analýzy semene pomocí počítače}

Cílem této studie bylo srovnání dvou protokolů kryokonzervace semene kozlů s využitím analýzy semene pomocí počítače. Dvacet ejakulátů bylo získáno elektroejakulací. Každý ejakulát byl rozdělen na dvě poloviny a zamražen dle dvou srovnávaných protokolů. U protokolu I bylo semeno odstředěno za účelem separace semenné plasmy a rozpuštěno v Tris pufru obsahujícím glukózu, kyselinu citrónovou a glycerol s prídavkem 20 \% vaječného žloutku. V rámci protokolu II nebyla separována plasma a pufr obsahoval 1,5 \% vaječného žloutku. Ukázalo se, že separace semenné plasmy zvýšila motilitu spermií po následném zmražení a rozmražení, dle následujících hledisek: motilita, průměrná rychlost pohybu, rozsah laterální dekapitace $(p<0,05)$, rychlost pohybu vpřed, propulzivita a linearita $(p<0,01)$. Z výsledků vyplývá, že separování semenné plasmy odstředěním zlepšuje motilitu kozlího semene při procesu zmražení a následného rozmražení.

\section{References}

KLIMOWICZ M, NIŻAŃSKI W, SAVIĆ MA, ZBYRYT I, DUBIEL A 2005: Ocena jakości nasienia psa przy zastosowaniu konwencjonalnej metody mikroskopowej, cytometru przepływowego oraz komputerowego analizatora jakości nasienia HTM IVOS. Med Wet 61: 1250-1255

LEBOEUF B, RESTALL B, SALAMON S 2000: Production and storage of goat semen for artificial insemination. Anim Reprod Sci 62: 113-141

RITAR AJ, SALAMON S 1983: Effect of seminal plasma and its removal and of egg yolk in the dilutent on the survival of fresh and frozen thawed spermatozoa of Angora goat. Aust J Biol Sci 36: 49-59

RITAR AJ, BALL PD, O’ MA PJ 1990: Examination of methods for the deep freezing of goat semen. Reprod Fertil Develop 2: 27-34

RITAR AJ, SALAMON S 1991: Effects of month of collection, method of processing, concentration of egg yolk and duration of frozen storage on viability of Angora goat spermatozoa. Small Ruminant Res 42: 9-37

TULI RK, SCHMIDT-BAULAIN R, HOLTZ W 1992: Computer-assisted motility assessment of spermatozoa from fresh and frozen-thawed semen of the bull, boar and goat. Theriogenology 38: 487-490

TULI RK, HOLTZ W 1994: Effect of glycerolization procedure and removal of seminal plasma on post-thaw survival and GOT-release from boer goat spermatozoa. Theriogenology 42: 547-555

VERSTEGEN J, IGUER-OUADA M, ONCLIN K 2002: Computer assisted semen analyzers in andrology research and veterinary practice. Theriogenology 57:149-179 